\title{
Underground nuclear parks: new approach for the deployment of nuclear energy systems
}

\author{
C. W. Myers ${ }^{1}$, J. M. Mahar ${ }^{2}$, J. F. Kunze ${ }^{2}$ \& N. Z. Elkins ${ }^{1}$ \\ ${ }^{1}$ Los Alamos National Laboratory, Los Alamos, New Mexico, USA \\ ${ }^{2}$ Idaho State University, Pocatello, Idaho, USA
}

\begin{abstract}
It is possible that hundreds to perhaps thousands of new nuclear power reactors could be deployed this century to help meet the growing global demand for electricity. Underground reactor siting is proposed as a potentially superior alternative to surface siting. Past studies and experience with underground siting proved the engineering feasibility and revealed numerous safety, security, environmental and aesthetic advantages, but in spite of these advantages the added cost associated with underground siting continues to be viewed as an impediment. Recent work on the underground nuclear park (UNP) concept, however, indicates the potential to reduce per-reactor capital and operating cost below that for conventional surface siting. In addition, under a closed fuel-cycle policy, reprocessing plant, fuel re-manufacturing facilities, fast spectrum reactor(s), and waste disposal facilities could also potentially be located underground as part of the UNP. Work to date has included underground design concepts and excavation cost estimates for UNPs in bedded salt and granite, and ideas for UNP-based energy system applications. The UNP approach has the potential to reduce many of the cost, waste management, safety, and security concerns currently associated with nuclear power.
\end{abstract}

Keywords: underground nuclear park, nuclear reactors, nuclear fuel cycle, underground reactor siting, cost reductions, waste management, security, safety.

\section{Introduction}

Nuclear energy is increasingly recognized as an important technology to help meet the growing global demand for multi-gigawatt levels of baseload electricity 
on a reliable and sustainable basis, and to reduce air pollution and the emission of greenhouse gases. Nonetheless, divergent and often passionate views continue to be held regarding the issues of security and safety of nuclear reactors, the economics of nuclear power, and the proliferation and environmental risks associated with nuclear material and waste produced by nuclear power reactors.

The premise of this paper is that a significant expansion of nuclear power will ultimately result in response to growing recognition of the environmental and energy security advantages of nuclear power. Currently, 439 operating reactors produce $16 \%$ of the world's electricity, and an additional 34 are under construction with 365 either on-order, planned or proposed [1]. Assuming a significant global expansion, global growth could reach 1000 total deployed reactors by mid-century, according to a Massachusetts Institute of Technology study co-chaired by J. Deutch and E. J. Moniz [2], and perhaps even 8,000 to 10,000 reactors by the end of this century according to J. Ritch, Director General of the World Nuclear Association [3]. Given the possible deployment of 1000plus reactors over the coming decades, the question arises of whether there might be a way to reduce beyond current levels the risks and costs associated with construction and operation of nuclear reactors relative to conventional, surfacesited reactors, and to increase their margins of safety, security and proliferation resistance. Underground siting is one possibility.

Underground space is an under-appreciated natural resource that could be utilized to facilitate the global expansion of nuclear power. Underground siting of several nuclear reactors and the waste management, reprocessing, and fuel remanufacturing facilities supporting those reactors at a single location to form an underground nuclear park (UNP) could be an attractive alternative to conventional deployment and surface siting of these facilities.

This paper summarizes work to date on the UNP concept.

\section{Past experience and studies of underground reactor siting}

Three reactors were sited underground in 1958, 1961, and 1964 in a large granite rock mass near the Yenisey River in Central Siberia, Russia [4]. Bach [5] described small underground test and research reactors installed in the 1960s in Norway, Sweden, and Switzerland, and a small power plant in France The decades-long success of the Russian reactor operations and the European experience demonstrated the technical feasibility of operating nuclear reactors underground. Also, studies of underground reactor siting in the 1970s in the U.S.A., Canada, Japan, and Switzerland confirmed the technical feasibility and revealed many safety, security and other advantages, but concluded that underground construction could have a cost and schedule penalty [6]. Interest in nuclear power, as well as underground siting, waned in the late 1970s and 1980s in the wake of the Three Mile Island and Chernobyl accidents and growing public opposition to nuclear power. The exception appears to have been in Russia where interest in underground siting continued into the 1990s and was viewed, for example, by Dolgov [7] as being potentially economical, with advantages in operational safety and physical security. 
Especially noteworthy is the fact the eminent $20^{\text {th }}$ century physicists Andrei Sakharov and Edward Teller both saw nuclear energy as essential for the future of humanity and both advocated underground siting as a means to assure safety, even under extreme accident situations, and to promote greater public acceptance $[8,9]$.

\section{Underground Nuclear Park}

\subsection{Original UNP concept}

Introduction of the underground nuclear park (UNP) concept in 2004 by Myers and Elkins [10] expanded the possible approaches to underground reactor siting. The number of reactors to be sited underground was increased from one to as many as 18 , and the spent fuel storage facility and waste repository supporting those reactors was collocated underground along with the reactors in an openfuel-cycle configuration (Figure 1). The 2004 UNP concept included hightemperature reactors and heat exchangers sited 200 meters deep in a thick, bedded-salt rock host rock. Multi-gigawatt levels of produced electricity were to be supplied to users by a high-capacity transmission system. Arguments were presented indicating that the life-cycle cost of electricity from the UNP would be less than under conventional surface siting and waste management approaches, and the level of public acceptance would be greater. Normal underground hazards such as fire and hazardous gases were recognized as needing analysis, as was a safety analysis to evaluate accident scenarios.

Studies completed in 2006 by Myers et al [11] indicated the UNP approach would lead to reduced per-reactor cost for construction, operations, security, and waste management relative to an equivalent number and type of conventional surface-sited reactors. Other advantages included increased margins of operational safety, security against attack, and protection against severe weather effects. Conceptual layout and preliminary excavation cost estimates were given for a hypothetical UNP with 18 reactors and their turbine/generators sited in an array of individual chambers at a depth of 100 to 300 meters in bedded salt. Collocation of waste management facilities underground with the reactors would reduce waste transportation cost, associated health and safety risks, and public concern. Environmental justice would be promoted because by collocating the reactors and waste management facilities at the same location the community that benefited economically from the construction and operation of the reactors would be the same community that accepted the waste from the reactors.

\subsection{Closed-fuel-cycle UNP concept}

Recently, through the Advanced Fuel Cycle Initiative and Global Nuclear Energy Partnership, the U.S.A. has begun to examine technologies for an improved closed-fuel-cycle to further reduce the risk of proliferation, minimize nuclear waste, and maximize energy recovery - as well as promote the expansion of nuclear energy in the U.S.A. and in other nations. 
As a result, Mahar et al [12,13] developed a UNP concept for a closed-fuelcycle based on a granitic host rock and tunnel boring machine (TBM) excavation. In a closed-fuel-cycle UNP, a reprocessing plant, fuel remanufacturing facility and fast spectrum reactor(s) are collocated underground along with the power reactors, spent fuel storage facility and repository (Figure 1). There would be $10-15$ power reactors, using the $1000 \mathrm{MWe}$ light water reactor (LWR) as the unit. This number and capacity would produce sufficient quantities of spent fuel to justify a reprocessing plant and fuel re-manufacturing facility that, based on nominal designs, could be sized and dedicated to serving those reactors. Nuclear waste produced during reprocessing and fuel remanufacturing would be disposed of in the UNP repository. Reactor decommissioning could be accomplished by in-place burial inside the UNP. (Although not included to date as part of the UNP concept, it is possible that underground siting of uranium enrichment facilities as part of a UNP would also be possible.)

An important implication of the closed-fuel-cycle UNP concept is that - to a first approximation - enriched uranium fuel would enter the UNP and nuclear energy would exit, and nothing else. For the reactors in the UNP, the back end of the fuel cycle would therefore be completely closed and permanently contained underground at this single location. Risks to public health and worker safety associated with conventional decommissioning and nuclear waste transport would be largely eliminated, and the cost of those activities would be a fraction of current cost.

\subsection{Underground openings layout and construction}

Conceptual design of the closed-fuel-cycle UNP includes a TBM-excavated, 15meter diameter, main tunnel having a rectangular footprint with 610 meter minimum-length sides. Two 12 - 24 meter shafts provide equipment and personnel access to the tunnel. Drill and blast and/or additional TBM operations would be used to increase the height of the tunnel as needed. The tunnel is subdivided using bulkheads to create individual chambers 150 meters in length. The LWRs, steam generators, and condensers are placed in openings excavated below the tunnel invert, and the turbine/generator units are installed on the floor of the tunnel. The spent fuel pool is in a chamber adjacent to the tunnel. Independent access to the main tunnel is through adits connecting a second smaller tunnel driven parallel to the main tunnel.

\section{Reduced capital and operating cost}

Economic issues continue to be a constraint on the expansion of nuclear power. Although the UNP concept has inherent safety, security, and other advantages over conventional surface-siting of nuclear power plants, deployment of UNPs will probably not occur if there is a significant economic disadvantage. The economic viability of the UNP concept will be determined primarily by the life- 
cycle unit cost of power from a UNP relative to that from an aggregate of conventional nuclear power installations with similar capacity.

Past work identified several means by which the UNP concept might reduce capital and operating cost. Key among these are reduction of spent fuel and nuclear waste transportation cost, elimination of the containment structure, inplace decommissioning, and reduced security, maintenance, and insurance cost. Severe-weather related risks and its associated cost would also be reduced by being underground, as would earthquake risk.

The life-cycle unit-cost of power generated at a given nuclear power installation is dominated by the capital cost. Although the capital cost would be high for the first reactor installed in a UNP, the expectation is that the per-reactor cost would decrease significantly as the construction of subsequent reactors proceeded. This cost decrease would result from sharing the cost of common access shafts and tunnels among several reactors and from other factors pointed out in a University of Chicago study [14]; these include continuous construction of multiple units at a single site, use of standardized reactor designs, and maintaining a continuing on-site work force. The potential to incorporate preexisting underground space as part of the UNP could also lower underground construction cost.

\subsection{Reduced commodity cost}

A recent study of nuclear power sponsored by The Keystone Center [15] noted an escalation beginning in 2003 in the cost of steel, cement and other construction materials. This could be an increasingly important issue in the cost of new surface-sited nuclear power plants because the construction of the containment structure, reactor building, nuclear fuel handling facilities, turbinegenerator building, and the auxiliary buildings requires large quantities of concrete and structural steel. In contrast, creation of underground space for facilities usually involves the net removal of material (rock), not the addition of material. The rock remaining after excavation - reinforced as necessary provides the structural support normally provided by concrete, steel, and lumber in conventional surface-sited buildings. In addition, in the underground there is no need to construct thick walls of nuclear-grade concrete for radiation shielding and containment because sufficiently-thick rock-mass walls would serve this function. Therefore, at a suitable site, less steel and concrete would be needed to create an underground nuclear park relative to the quantities required for surfacesited reactors with similar aggregate capacity. Lastly, the UNP approach offers the potential to avoid not only the use of large quantities of concrete and steel for nuclear power plant construction, but to also avoid much of the risk and economic uncertainty associated with the potential for further cost increases in these commodities.

\section{UNP-based energy systems}

A UNP could be the foundation for an energy system to produce baseload electricity, peaking electricity, hydrogen, oxygen, desalinated water and process 
heat. Off-peak electricity from the UNP power plants could be used to compress and store air underground in solution- or mechanically-mined caverns that would be released during higher demand periods for use in gas turbines to supply peaking power. This is proven technology known as compressed air energy storage (CAES), see Crotogino and Mohmeyer [16] for a description of CAES.

Electricity from the UNP could be used to produce hydrogen by electrolysis, or, alternatively, a UNP with high-temperature reactors could supply high temperature process heat to thermo-chemically dissociate water as per processes described by Uhrig [17] in his review of options for producing hydrogen using nuclear energy. The produced hydrogen and oxygen could then be stored as a compressed gas in underground caverns near the UNP from which it could be periodically withdrawn for use in fuel cells, for example, as described by Forsberg [18]. Also, it is possible that the stored oxygen could be used in gasification combined cycle (IGCC) plants enabling a pure stream of $\mathrm{CO}_{2}$ to be produced, as described by Kunze et al [19], for subsequent sequestration, enhanced oil production or other uses. Waste heat from a UNP could be used for desalination of sea water, or in inland areas for desalination of water drawn from deep saline aquifers.

\section{Summary and recommendation}

The UNP is a new application of the earth's underground space resource. Relative to the conventional approach to site nuclear power plants at the earth's surface, the UNP approach can potentially provide lower capital and operating cost, a more equitable approach to nuclear waste management, greater levels of protection for nuclear material, and increased margins of operational safety and physical security.

Nations contemplating construction of new reactors, reprocessing facilities, or fuel re-manufacturing facilities should consider the UNP as an option, and undertake the engineering and economic analysis necessary to evaluate its merits with regard to their needs.

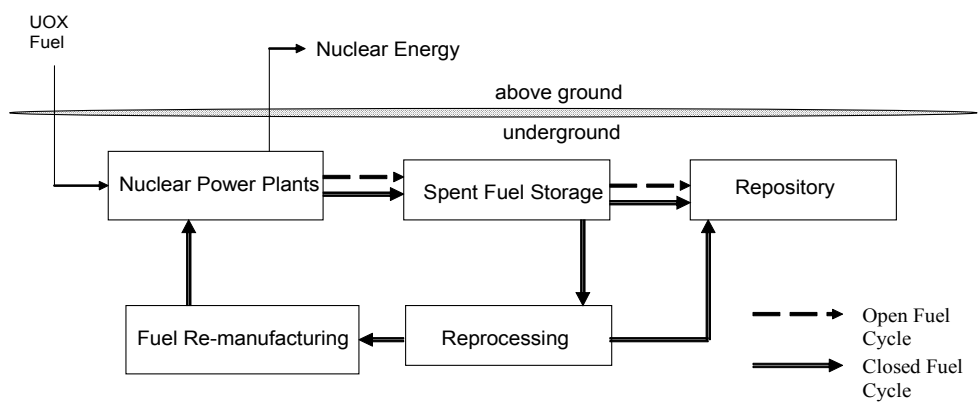

Figure 1: Underground nuclear park components and material flow relationships. 


\section{References}

[1] World Nuclear Association, “ World Nuclear Power Reactors 2006-2008 and Uranium Requirements, 14 January 2008," http://www.worldnuclear.org/info/reactors.html.

[2] Massachusetts Institute of Technology, "The Future of Nuclear Power," http://web.mit.edu/nuclearpower.

[3] Ritch, J., "The Necessity of Nuclear Power: A Global Human and Environmental Imperative," Speech at the World Nuclear AssociationWorld Nuclear University, Senior Executive Dinner, London, UK, January 29, 2008.

[4] Global Security, "Krasnoyarsk-26/Zheleznogorsk Mining and Chemical Combine [MCA] N $56^{\circ} 22^{\prime}$ E $93^{\circ} 41^{\prime}$," http://www.globalsecurity.org/wmd/ world/russia/krasnoyarsk-26_nuc.

[5] Bach, P.J., "A Summary of Studies on Underground Nuclear Power Plant Siting," Underground Space, 2(1), pp. 47-51, 1977.

[6] Bender, H.F., (Ed.), Proceedings of a Symposium on Underground Siting of Nuclear Power Plants, E. Schweizerbart'sche Verlagsbuchhandlung, Stuttgart, Germany, 412 p, 1982.

[7] Dolgov, V.N., "Inherently Safe Power-Generating Unit for an Underground Nuclear Power Plant," Atomic Energy, 76(2) pp. 136-138, 1994.

[8] Sakharov, A.D., Memoirs, Alfred A. Knopf, Inc., New York, pp. 612 - 613, 1990.

[9] Teller, E., Memoirs, Perseus Publishing, Cambridge, Massachusetts, p. 564, 2001.

[10] Myers, W., and Elkins, N., "Siting nuclear power plants underground: Old idea, new circumstances," Nuclear News, 47(3) pp. 33-38, 2004.

[11] Myers, C.W., Elkins, N.Z., Kunze, J.F., and Mahar J.M., "Potential Advantages of Underground Nuclear Parks," Proceedings of the 14th International Conference on Nuclear Engineering, 14-8913, Miami, Florida, July, 17-20, 2006.

[12] Mahar, J.M., Kunze, J.F., Myers, C.W., and Loveland, R. "Advantages of Co-Located Spent Fuel, Reprocessing, Repository and Underground Reactor Facilities", American Nuclear Society, Advanced Nuclear Fuel Cycles and Systems, Boise, Idaho, September 9-13, 2007.

[13] Mahar, J.M., Kunze, J.F., and Myers, C.W., "Underground Nuclear Power Parks - Power Plant Design Implications," Proceedings of the $16^{\text {th }}$ International Conference on Nuclear Engineering," 16-48889, Orlando, Florida, May 11-15, 2008.

[14] The University of Chicago, "The Economic Future of Nuclear Power, A Study Conducted at the University of Chicago, August 2004," http://www.ne.doe.gov/reports/NuclIndustryStudy.pdf.

[15] The Keystone Center, "Nuclear Power Joint Fact Finding", http://www.keystone.org/spp/documents/FinalReport_NuclearFactFinding6 2007(2).pdf. 
[16] Crotogino, F., and Mohmeyer, K.U., "Huntorf CAES: More than 20 Years of Successful Operation, Spring 2001 Meeting of Solution Mining Research Institute, Orlando, Florida, April 23 - 25, 2001.

[17] Uhrig, R.E., "Producing Hydrogen Using Nuclear Energy," Proceedings International Hydrogen Energy Congress and Exhibition, Istanbul, Turkey, July $13-15,2005$.

[18] Forsberg, C.W., "Synergistic Benefits of a Nuclear-Renewable Hydrogen Economy," $17^{\text {th }}$ Annual U.S. Hydrogen Meeting, Long Beach California, March 12 - 16, 2006.

[19] Kunze, J. F., Sandquist, G.M., and Pardo, D.M., "Is Nuclear Power Also the Key to Economically Clean Coal Gasification," Proceedings International Conference on Nuclear Engineering, Miami, Florida, July 17 $-20,2006$. 